\title{
Pintatias
}

\section{Acerca de la obra de Segundo Arístides Huertas Torres}

\author{
Gabriel Ruiz Montes
}

Es increíble pensar como las buenas obras no tienen una nacionalidad determinada, lo universal del arte está reflejado en cada uno de los trazos de la maravillosa pintura de Segundo Huertas.

Nació en Piura, Perú, pero de corazón y crianza huilense, es un orgullo para el patrimonio cultural no solo de los opitas, sino en general para Colombia, quien lo ha recibido como un hijo talentoso que nos hace vibrar con sus cuadros, invitando a la imaginación a interpretar sus musas, sus colores y su inspiración en ese gran regalo que ofrece cuando toma el pincel y al final encontramos plasmado ese derroche pictórico tan propio pero a la vez tan nuestro.

Fundamentalmente para el maestro Huertas ha sido la profundización del papel de la mujer Latinoameri- cana en cada una de las actividades cotidianas donde quizás lo más bello que tiene para ofrecer fuera de la tenacidad, la fortaleza y la belleza física, es sobre todo el amor.

Ese amor encontrado en su Motor del alma como el mismo describe a su compañera de vida, a su amiga, a su mejor aliada, a ese bastón en el andar por el camino del artista, siempre de la mano de Anyely.

Las costumbres huilenses nunca las ha hecho a un lado a pesar de residir en Bogotá, por el contrario esa conexión de olores, sabores y sobre todo colores lo invaden con frecuencia en su estudio de pintura donde todo se alinea para la creación artística del maestro Huertas.

Segundo Arístides Huertas Torres nombre completo de pila de este gran escultor y pintor a quien tenemos entre nosotros en su exposición, admirando sus recientes creaciones y quizás una que otra anécdota de su proceso artístico, es motivo de encuentro para recrear no solo la vista, sino el alma que seguramente se enredará en cualquiera de sus pinturas.

Es un placer desde mi trinchera de admirador escribir de tan fabuloso ser humano y artista que hace revivir mi alma huilense por adopción, al recordar mis años vividos en tan lindas tierras y reconocer la dedicación a su trabajo. 


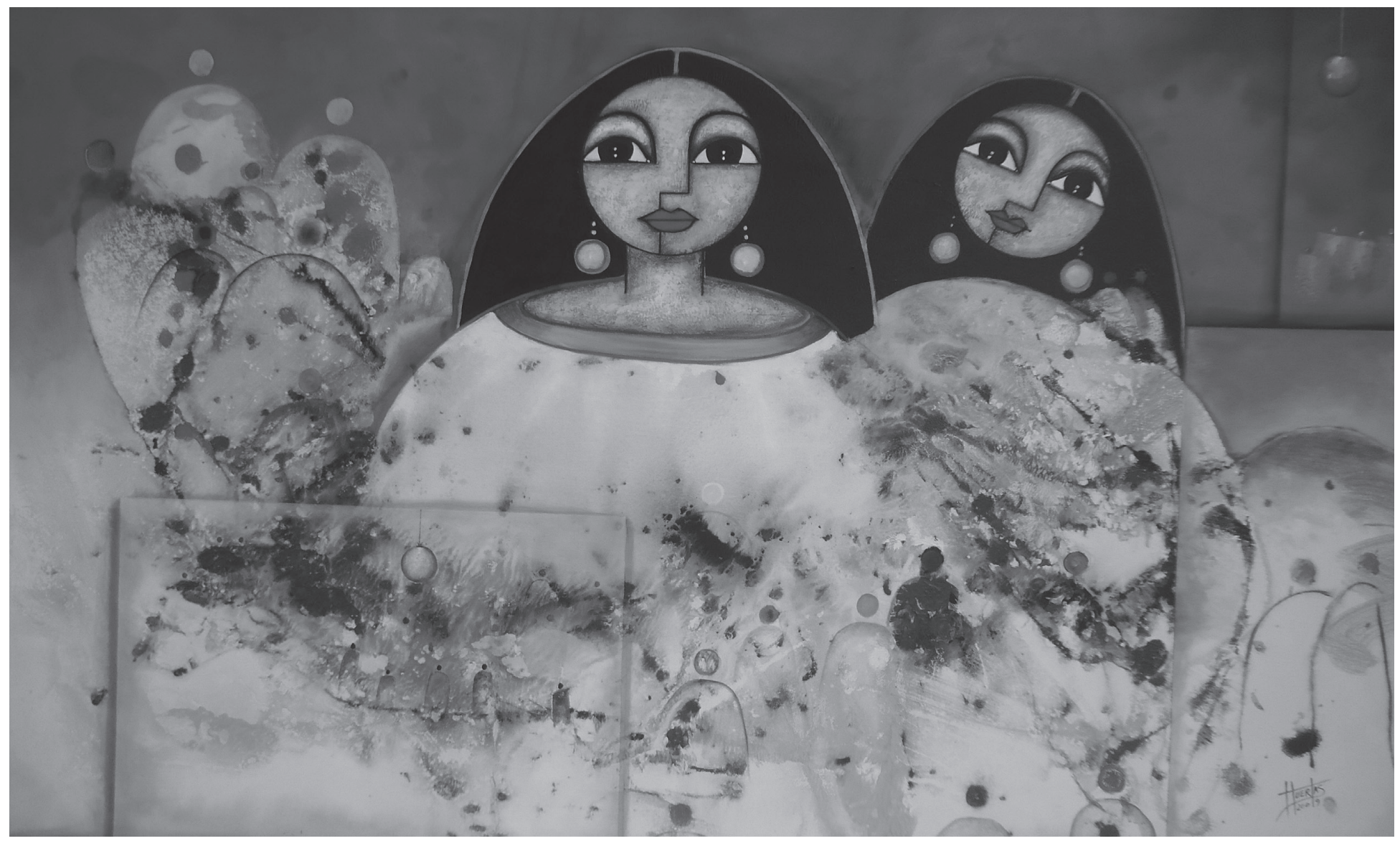

Segundo Arístides Huertas Torres ॥ Título: De la serie Ventana a un nuevo mundo \#Técnica: Mixta sobre tela 》 Dimensiones: $120 \mathrm{~cm}$ x $180 \mathrm{~cm}$ 